\title{
Erratum to: "We're Working in the Dark Here": Education Needs of Teachers and School Staff Regarding Student Self-Injury
}

\author{
Emily Berger $\cdot$ Penelope Hasking $\cdot$ Andrea Reupert
}

Published online: 22 October 2014

(c) Springer Science+Business Media New York 2014

Erratum to: School Mental Health (2014) 6:201-212

DOI 10.1007/s12310-013-9114-4

The original version of this article unfortunately contained two mistakes.

On page 206, the last sentence of the paragraph titled "Exposure to NSSI and Education Needs" should read as "Interestingly, among school mental health workers, less than a third $(22.9 \%)$ had never received education, and
$75.4 \%$ felt they needed education in NSSI". The word "never" was missed in the original publication.

On page 204, the last line of the paragraph titled "Data Analysis" should read as " 245 participants was required fewer than our sample of 501". "513" in the original publication should have read as " 501 ".

The authors regret the inconvenience caused in this regard.

The online version of the original article can be found under doi:10. 1007/s12310-013-9114-4.

E. Berger · A. Reupert

Faculty of Education, Monash University, Clayton, Melbourne,

VIC 3800, Australia

P. Hasking $(\bowtie)$

School of Psychology and Psychiatry, Monash University,

Clayton, Melbourne, VIC 3800, Australia

e-mail: Penelope.Hasking@monash.edu 